\title{
AN IMPROVED APPROACH TO THE SUBCONTRACTING PROCUREMENT PROCESS IN A LEAN CONSTRUCTION SETTING
}

\author{
Samuel Yen-Liang YIN ${ }^{\mathrm{a}, \mathrm{b}}$, H. Ping TSERNG ${ }^{\mathrm{c}}$, Shih Ning TOONG ${ }^{\mathrm{b}}$, Thanh Long NGO ${ }^{\mathrm{d} \text { e }}$ \\ ${ }^{a}$ Department of Civil Engineering, National Taiwan University, No. 1 Roosevelt Rd., Sec. 4, Taipei, Taiwan \\ ${ }^{b}$ Ruentex Group, 14F., No. 308, Section 2, Bade Road, Taipei, Taiwan \\ ${ }^{c}$ Department of Civil Engineering, National Taiwan University, No. 1 Roosevelt Rd., Sec. 4, Taipei, Taiwan \\ ${ }^{d}$ Div. of Construction Engineering and Management, Department of Civil Engineering, \\ National Taiwan University, No. 1 Roosevelt Rd., Sec. 4, Taipei, Taiwan \\ ${ }^{e}$ Department of Construction Mechanical Engineering, National University of Civil Engineering, \\ No. 55 Giaiphong Rd., Hanoi, Vietnam
}

Received 22 Dec 2011; accepted 11 Apr 2012

\begin{abstract}
The subcontracting procurement process is one of the most important issues impacting the costs of engineering projects and construction projects, in particular. Traditional procedures of subcontracting procurement tend to limit the opportunities for price negotiation and cooperative relationships between contractors and neglect potential issues such as engineering interface, construction risk, and waste. Based on case studies of construction projects, we propose a "lean" subcontracting procurement process (LSPP) drawing from lean construction theory. The process consists of a novel Seven-Arrangement operation plan and four types of standard operating flows. Not only does the proposed LSPP help subcontractors eliminate various types of waste in construction projects, it also establishes a common information platform and cooperative environment that help participating contractors understand the work emphasis of each operation and the whole operation in sequence. As a result, the relationships between participating contractors become cooperative, potential risks in construction projects can be discovered early, and profits are shared between contractors. Thus, this process allows contractors to obtain long-term benefits.
\end{abstract}

Keywords: lean construction, subcontracting procurement process, waste management, subcontractor.

Reference to this paper should be made as follows: Yin, S. Y.-L.; Tserng, H. P.; Toong, S. N.; Ngo, T. L. 2014. An improved approach to the subcontracting procurement process in a lean construction setting, Journal of Civil Engineering and Management 20(3): 389-403. http://dx.doi.org/10.3846/13923730.2013.801900

\section{Introduction}

The subcontracting procurement process is one of the most important issues impacting the costs of construction projects and the whole construction industry for several reasons. First, although the costs of procurement often relate to waste levels, construction methods, on-site environment, working path, economies of scale, and market rates, these important factors are frequently overlooked when determining procurement costs. Second, the subcontracting procurement process tends to be overly constrained by market rates, which cause a high level of cost growth and by engineering practices, which contain numerous details, procedures, interfaces, and risks that prevent lower costs and performance improvement. Third, the level of waste in construction projects tends to be very high. For example, $46 \%$ of unproductive working time is due to late arrival or early departure (3\%), waiting and idling (32\%), waiting for tools or material $(5 \%)$, and waiting for instruction (6\%) (American Association of Cost Engineers 1992). Up to $30 \%$ of construction costs is due to inefficiencies, mistakes, delays, and poor communication (Forbes, Ahmed 2004). Furthermore, 10\% to $20 \%$ of the total project cost is spent on rework (Cnudde 1991; Burati Jr et al. 1992). These types of waste add to the project cost. Fourth, the level of risk involved in construction projects is very high (Abdelgawad, Fayek 2010), causing frequent underestimation of cost and time (Zavadskas et al. 2009). Thus, incomplete planning and insufficient consolidation of information not only lead to underestimated procurement times but also create massive problems for the project participants downstream in the value chain by requiring more time, resources, material, manpower, and money. All of this occurs in the absence of improved product quality or increased productivity. Fifth, most of the construction work in the project is performed by subcontractors. Subcontractors may account for as much as $80-90 \%$ of the total value of the construction project (Hinze, Tracey 1994). As experts in the execution of a specific procedure, subcontractors supply personnel, materials, equipment, tools, and designs (Shimizu, Cardoso 2002). 
Despite the many studies on the procurement of subcontractors, the focus of these studies has been limited to the selection of a subcontractor (Kumaraswamy, Matthews 2000; Arditi, Chotibhongs 2005), subcontractor selection criteria (Greenwood 2001; Hartmann et al. 2009; Hartmann, Caerteling 2010; Radziszewska-Zielia 2010, etc.), and subcontractor rating techniques (Albino, Garavelli 1998; Eom et al. 2008). Moreover, these studies do not address how a subcontractor might eliminate waste, predict risk, and achieve cooperative relationships with other contractors during the procurement and construction processes.

The traditional process of procuring subcontractors tends to be based on price negotiation and price competition, with the goals of lowering the costs associated with labor, machine, and material; maintaining quality; and meeting the requirements of both the main contractor and the business owner. However, the traditional process limits the opportunities for price negotiation, for the majority of contractors negotiate prices only after being awarded contracts (Shash 1998). Additionally, because subcontractors prepare and submit quotations to all inviting contractors just a few hours before the main bid opening time, potential issues related to the engineering interface and construction risk are often neglected during price negotiation (Shash 1998). In addition, the traditional process of subcontracting procurement is often characterized by a typical lack of trust and cooperative relationship between contractors, despite the fact that trust and cooperation are key to project success (Eriksson, Laan 2007; Hartmann, Caerteling 2010) and competition is associated with conflicts, adversarial relationships, undesirable project results, and other negative outcomes (Pesämaa et al. 2009; Eriksson, Laan 2007). In contrast, cooperative procurement leads to the development of trust and cooperative relationships and positively influences project performance in terms of cost, time, quality, environmental impact, work environment, and innovation (Eriksson, Westerberg 2011).

As mentioned above, the waste level in construction projects tends to be very high. Therefore, reducing or eliminating waste has become a topic of considerable discussion in the construction field in recent years, with lean construction becoming a widely adopted theory. The theory helps contractors to reduce engineering waste and also to maximize production values. On the theoretical basis of lean construction theory, contractors can reduce construction time, lower costs, and achieve improved quality (Yu et al. 2009).

The idea of lean construction is derived from the related concept of lean production in industrial engineering. Whereas the concept of lean production was originally developed for the Toyota Motor production system during the 1950s, today, the lean theory is being implemented all over the world in such locations as Japan, the United States, and Europe (Abdullah 2003). Ohno (1987) suggested seven major factors that lead to waste in a production system, namely, over-production, waiting, transportation, processing, inventory, action, and defects. By eliminating these seven types of waste, lower costs can be achieved. Lean construction applies the concept of lean production from the manufacturing industry to the construction industry for the improvement of production. The goal of lean construction is to maximize value, reduce waste, and encourage resource sharing between all related parties.

In this research, we focus on case studies of construction projects and propose a lean subcontracting procurement process (LSPP) based on lean construction theory. The process consists of a novel Seven-Arrangement operation plan and four types of standard operating flows. The Seven-Arrangement operation plan is designed to help subcontractors eliminate various types of waste in construction projects. In addition, the four types of standard operating flows consist of steps that establish a common information platform for contractors and help each participating contractor understand the work emphasis of single operations and the whole operation in sequence. The effectiveness of the proposed process was verified in actual projects. The results include the development of cooperative relationships between contractors, early discovery of potential risk in construction, and the sharing of profits between contractors. With the full implementation of the lean subcontracting procurement process, the goals of eliminating waste, decreasing risk, establishing cooperative relationships, maximizing value, and other long-term benefits can be achieved.

\section{Seven types of waste and the principle of waste elimination}

\subsection{Seven types of waste}

In this section, we explain the types of waste that often appear in construction projects. Abdullah (2003) defined waste as "all kinds of activities in the production process that do not add value to the product". Waste in a construction project can be classified into seven types: waste from defects, waste from delays, waste from overproduction, waste from unnecessary processing, waste from maintaining excess inventory, waste from unnecessary transport, and waste from unnecessary movement of people and equipment (Pinch 2005). Table 1 presents the definitions, outcomes, and examples associated with each of the seven types of waste.

\subsection{Principle of elimination of waste}

The goal of this research is to propose arrangements that eliminate waste based on lean construction principle. Its primary principles include reducing change orders, creating an uninterrupted operating flow with the correct and opportune information, and establishing performance goals based on the results of the initial plan. At the same time, a corresponding strategy is generated from the principles to create a stable, uniform, and interdependent capacity to link flows and develop a set of standard operating procedures to further refine/improve the method of execution. A set of supervisory procedures can be designed to generate a cyclical mechanism to improve result at any time. This mechanism is explained in Figure 1. 
Table 1. Seven types of wastes in construction projects

\begin{tabular}{|c|c|c|c|}
\hline Waste & Definition & Result & Example \\
\hline $\begin{array}{l}\text { 1. Waste from de- } \\
\text { fects }\end{array}$ & $\begin{array}{l}\text { Incorporating products and mate- } \\
\text { rials of non-standard sizes or bad } \\
\text { quality into the production line, } \\
\text { increasing the amount of unnec- } \\
\text { essary handling or processing that } \\
\text { could affect the quality of the } \\
\text { product }\end{array}$ & $\begin{array}{l}\text { Unnecessary increase in sec- } \\
\text { ondary expenses of on-site } \\
\text { material, manpower, equipment, } \\
\text { and other resources }\end{array}$ & $\begin{array}{l}\text { Shipping steel bars of different } \\
\text { sizes to the site and allowing } \\
\text { arbitrary cutting on the site. Pro- } \\
\text { curement of electrical or mechan- } \\
\text { ical wiring or piping of non- } \\
\text { standard lengths }\end{array}$ \\
\hline $\begin{array}{l}\text { 2. Waste from de- } \\
\text { lays }\end{array}$ & $\begin{array}{l}\text { Idling operation or in-between } \\
\text { events }\end{array}$ & $\begin{array}{l}\text { Increase in cost of manpower, } \\
\text { imbalance in production }\end{array}$ & $\begin{array}{l}\text { Lifting operation waiting for } \\
\text { truck transporting beams. Pour- } \\
\text { ing operation waiting for the } \\
\text { completion of reinforcement cage }\end{array}$ \\
\hline $\begin{array}{l}\text { 3. Waste from over- } \\
\text { production }\end{array}$ & $\begin{array}{l}\text { Producing products earlier than } \\
\text { specified by customers or in } \\
\text { greater amounts than required }\end{array}$ & $\begin{array}{l}\text { Creating other types of wastes } \\
\text { such as excessive manpower, } \\
\text { transportation, storage space }\end{array}$ & $\begin{array}{l}\text { One-shot production of certain } \\
\text { kinds of wall panel, production of } \\
\text { large amount of fluorescent pow- } \\
\text { der material }\end{array}$ \\
\hline $\begin{array}{l}\text { 4. Waste from un- } \\
\text { necessary pro- } \\
\text { cessing }\end{array}$ & $\begin{array}{l}\text { Improper steps or stages in the } \\
\text { workflow }\end{array}$ & $\begin{array}{l}\text { Error in idling, reworking, and } \\
\text { safety procedures }\end{array}$ & $\begin{array}{l}\text { Arranging and repairing cement } \\
\text { grouting is in conflict with elec- } \\
\text { trical and mechanical work }\end{array}$ \\
\hline $\begin{array}{l}\text { 5. Waste from } \\
\text { maintaining excess } \\
\text { inventory }\end{array}$ & $\begin{array}{l}\text { Improper storage of raw material, } \\
\text { WIP (Work-In- Process), or fin- } \\
\text { ished product and improper se- } \\
\text { quence of use }\end{array}$ & $\begin{array}{l}\text { Increased in cost and consump- } \\
\text { tion of capital, leading to longer } \\
\text { lead time and hiding other prob- } \\
\text { lems such as uneven produc- } \\
\text { tion, supplier delay, or defective } \\
\text { product }\end{array}$ & $\begin{array}{l}\text { One-shot ordering of all kinds of } \\
\text { tiles needed in the project and not } \\
\text { storing tiles in an orderly se- } \\
\text { quence }\end{array}$ \\
\hline $\begin{array}{l}\text { 6. Waste from un- } \\
\text { necessary transport }\end{array}$ & $\begin{array}{l}\text { Improper transportation of parts } \\
\text { or finished goods in the process } \\
\text { flow }\end{array}$ & $\begin{array}{l}\text { Increase in manpower or cost. } \\
\text { Increased risk of product de- } \\
\text { fects }\end{array}$ & $\begin{array}{l}\text { Transport of parts produced to } \\
\text { temporary yard. Transport exces- } \\
\text { sive \#10 steel bars from site A to } \\
\text { site B for storage }\end{array}$ \\
\hline $\begin{array}{l}\text { 7. Waste from un- } \\
\text { necessary move- } \\
\text { ment of people and } \\
\text { equipment }\end{array}$ & $\begin{array}{l}\text { Unable to make proper use of } \\
\text { personnel or machine to add value } \\
\text { to work }\end{array}$ & $\begin{array}{l}\text { Increase in manpower require- } \\
\text { ment, time delay in operating } \\
\text { flow }\end{array}$ & $\begin{array}{l}\text { Selecting a plate of } 60 \mathrm{~cm} \text { width } \\
\text { from a pile of plates. Walking } 30 \\
\mathrm{~m} \text { and back to fetch a hammer to } \\
\text { nail the plate }\end{array}$ \\
\hline
\end{tabular}

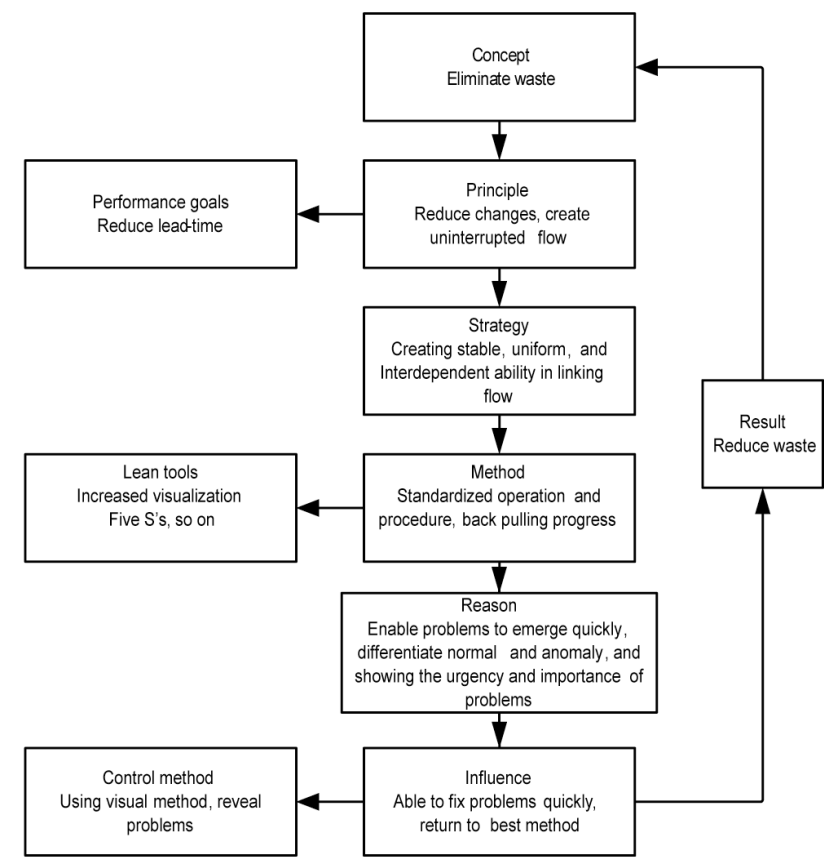

Fig. 1. Operating flow of recycling diagram for reducing waste

\section{The traditional subcontracting procurement process}

In a construction project, the procurement operational flow emphasizes lowering costs to enable the hiring of excellent subcontractors. However, the collective experiences from many procurement cases suggest that the initial subcontracting outcome does not guarantee that the final result will meet expectations, particularly given that most procurement personnel are not held responsible for the final result of each project. In addition, the success of each project is closely related to the procurement process (Cheung et al. 2001). Therefore, the procurement management needs to go beyond the traditional price competition (that is constrained by the aforementioned limitations) and define a standard operational flow that will improve performance and increase profit sharing through the effective communication and interface between individual but related components. To clearly define and measure a set of operational structures that meets the requirement of the construction site, properly controls subcontractors, and abides by company policy, the performance of the subcontracting department needs to be overseen by the project procurement personnel to facilitate communication between main contractors and subcontractors. 


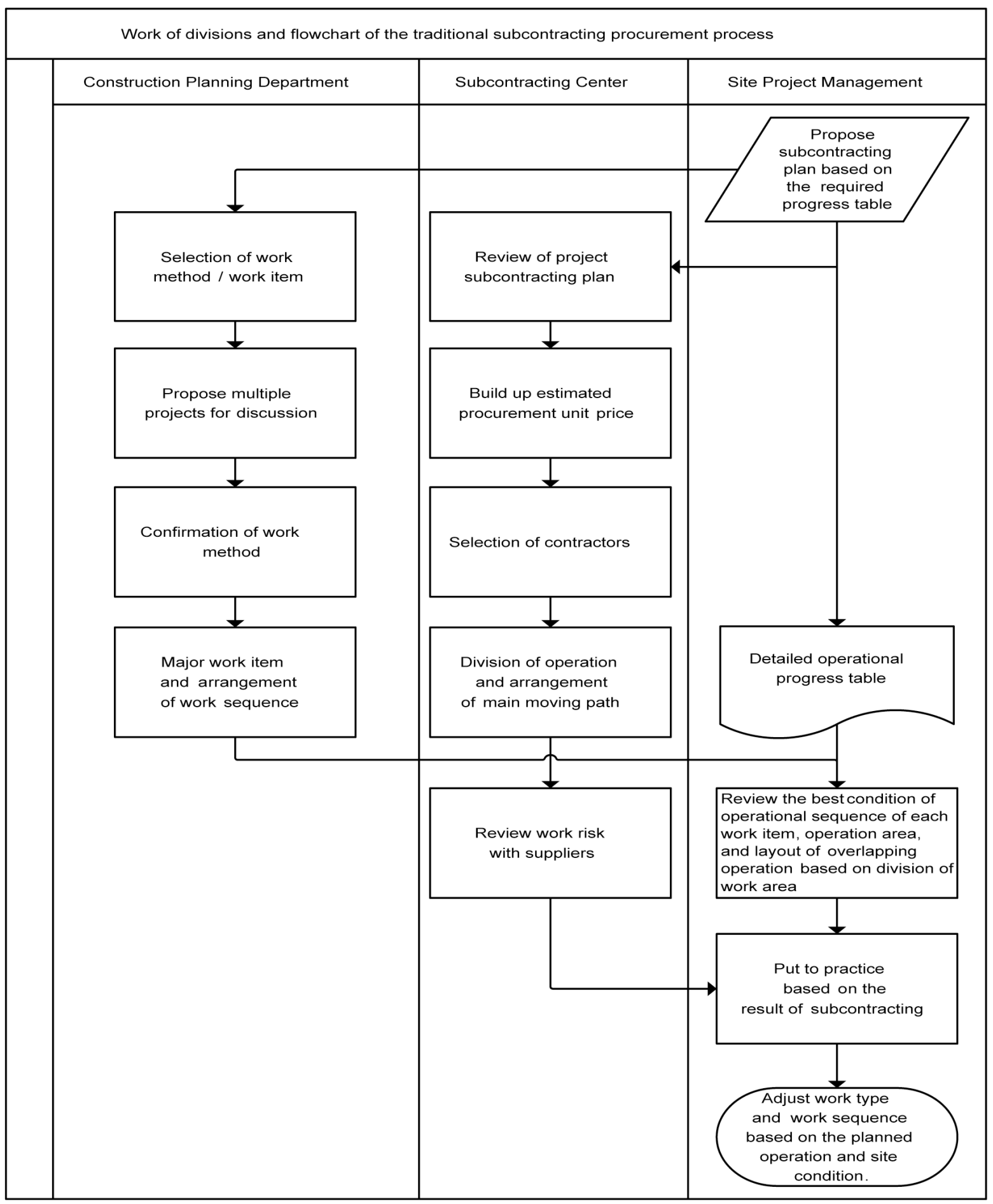

Fig. 2. Work of division and flowchart of the traditional subcontracting procurement process

One of the shortcomings of the traditional procurement process is lack of planning in terms of the procurement process and the operational sequence. Subcontractors may not know the operational sequence of the whole project and, as a result, experience difficulty in terms of integrating with other construction operations. Even the subcontractors are unaware of the real risks involved and the ways in which the operational requirement could satisfy the construction site. Therefore, this research will investigate the traditional procurement flow and address the problems that emerge from the investigation.
As shown in Figure 2, the traditional subcontracting procurement process is typically implemented by three related parties: the Construction Planning Department, the Subcontracting Center, and the Site Project Management. The process includes the integration of steps such as designing, planning, subcontracting, executing, budgeting, and the closing of the account based on the timeline set by the unit of execution, and also prepares the consolidation table for the execution of the whole construction project. The figure below explains the operational flow of each related party. 


\section{(1) Construction Planning Department}

Immediately after the Site Project Management proposes a subcontracting plan, the Construction Planning Department starts operation. First, the Construction Planning Department reviews the content of the plan and associated guidelines given the content of the subcontracting plan. Then, multiple projects are proposed, reviewed, and subjected to, value and engineering analyses for an overall comparison of quality, cost, and duration. Finally, the report is discussed at a construction planning meeting and the chosen method is transferred to the construction site for execution.

\section{(2) Site Project Management}

Based on the required timeline, the Site Project Management proposes a subcontracting plan by reviewing the operating sequence, operating zone, and overlapping operation layout of each work item taking into account the division of construction area before actual execution. Consequently, the type and sequence of construction are adjusted in accordance with the plan and construction situation.

\section{(3) Subcontracting Center}

In a traditional operation, the major procurement operation is considered complete after price negotiation between the Subcontracting Center and Subcontractors. A competition for profits between the main contractor and the subcontractor is very clear. The procurement is often based on the extent to which a subcontractor agrees to lower his expected profit such as price. A lower price may reduce the quality of the construction project, prolong the construction duration, lead to cost overrun, increase the number of claims and litigation from the subcontractor, and so on (Hatush, Skitmore 1998).

After the Construction Planning Department reviews and selects the construction method, completes the arrangement of important work items and finalizes the construction sequence, the plan is immediately forwarded to the Site Project Management and the Subcontracting Center. The Subcontracting Center will select specialized contractors by following the fixed internal procurement operational flow based on price negotiation. This disconnected operational flow results from the fact that the Construction Planning Department, the Subcontracting Center, and the Site Project Management do not share a common information platform. Additionally, in the traditional procurement operational flow, the subcontractors are situated under the Subcontracting Center, with their responsibility being to provide a price quote to the Subcontracting Center. Therefore, based on the problems revealed in the traditional flowchart, we propose an approach including novel arrangements that can carry out the functions contained in the construction flowchart at a higher performance level by the implementation of lean technology and management through effective communication and consolidation.

In conclusion, an analysis of the traditional subcontracting procurement process reveals several limitations. Firstly, the process lacks a detailed operation plan for eliminating waste. Secondly, the process lacks a common information platform between contractors. Thirdly, the process leads to competitive relationships between contractors.

\section{Basic concepts of a lean subcontracting procurement process}

A crucial goal common to all construction projects is to lower the cost of the project. Site management and performance of the subcontractor represent two key factors that influence cost, with subcontractor cost being more important and contributing directly to the cost performance of the site. From a procurement standpoint, it is advisable to adopt a purchasing strategy that enhances customer satisfaction by emphasizing profit sharing. This type of strategy strengthens the interface of project execution, eliminates risk, reduces waste, and promotes information exchange. While exerting control over construction specifications, work regulations, R\&D, budget estimation, and subcontracting through large-scale industrialization, a construction company can achieve lean technology and management through effective communication and integration aimed at improving performance.

The basic principle of "lean" involves "identifying and eliminating waste in all activities" and consists of a set of tools and skills. The meaning of "lean" comes from the need to lower costs and improve performance, and should represent a shared mode of thinking and management approach across every operating flow. Due to the importance of addressing the root problem by understanding the true cause of barriers, we propose the concept of novel arrangements that can be practically applied to solve problems in the subcontracting procurement process.

In a narrow sense, the arrangements represent the standardization of an operation. Overall performance improvement and lower operating costs are achieved by converting all operations into production lines to reduce waste, provide moving paths, improve work efficiency, and reduce cost via concepts of industrial engineering. The purpose of standardization is to analyze and understand the incurrence of waste in the operating flow. Recording the operating procedure provides a visual representation of waste situation that may reveal the opportunities for improvement. From the procurement perspective, the main objectives of the novel arrangements and the four standard operating flows are to provide a process for supply collaboration through an effective engineering plan, information communication, consolidation, and a cooperative environment. In the following discussion, we use the definition of "waste" and related concepts to develop our approach to resolving the issue of "waste".

\section{A seven-arrangement operation plan}

In this section, we define the factors corresponding to the seven types of waste typically observed in construction projects (please refer to the section "Seven Types of Waste" for a description of each type of waste). The factors are called the Seven Arrangements and include quality arrangement, quantity arrangement, time arrangement, 
inventory place arrangement, the arrangement of task number and order, path arrangement, and location arrangement. The Seven Arrangements with their corresponding definitions and handling principles are summarized in Table 2.

Quality arrangement (size and specification): the specifications and sizes of all material and other resources delivered to the plant must match the design diagram to reduce the resources and manpower needed for secondary processing or reworking.

Quantity arrangement, time arrangement, and inventory place arrangement: material and other resources must match the specifications in the plan, correspond to a fixed 3-dimensional space, and be stored on schedule and with codes to facilitate search. Production should not be paused as a result of resource mismanagement.

The arrangement of task number and order, path arrangement, and location arrangement: any construction process, moving path, and location of the resources need to be executed with precision in the production process.

The Seven-Arrangement operation plan highlights several important characteristics of a successful organization: simplicity, clarity, traceability, and ease of implementation. The traditional operation plan is based on the site project, with the Construction Planning Department and Subcontracting Center being passive and providing clearance and explanation only when necessary. Most of the issues concerning detail, interface, sequence, and elevation are only resolved during execution. The SevenArrangement operation plan differs from the traditional plan in the way it dissects the project in advance and passes on the planning information from the procuring end to the actual executor (i.e. contractors, site projects, etc.). Hence, the Seven-Arrangement operation plan makes a smoother construction flow possible, ensures the on-time supply of resources such as material, and equipment, and effectively eliminates the aforementioned types of waste.

Furthermore, after applying the Seven-Arrangement operation plan and completing front and end planning operations, the purchaser should explain this information to contractors. The purpose is to seek the cooperation of contractors by developing common understanding and that forms the basis for executing the plan. Therefore, the model must be promoted from the inside out. A SWOT analysis can be performed to analyze the advantages, weaknesses, internal opportunities, and external threats that result from the promotion of Seven Arrangements. Though structurally simple, a SWOT analysis could help to simplify the complicated nature of the Seven Arrangements and reveal potential weaknesses and threats. Additionally, the results of the analysis may help to prevent the subcontractor from ignoring potential risks and defects when designing their strategy.

\section{A lean subcontracting procurement process (LSPP)}

Under the lean subcontracting procurement process (LSPP), the construction operation is executed through the collaboration of four interrelated parties. In addition

Table 2. Definition, handling principle, and waste reduction ability of the Seven-Arrangement operation plan (seven factors)

\begin{tabular}{|c|c|c|c|}
\hline Factor & Definition & Handling principle & $\begin{array}{c}\text { Reduced } \\
\text { waste from }\end{array}$ \\
\hline $\begin{array}{l}\text { 1. Quality } \\
\text { Arrangement }\end{array}$ & $\begin{array}{l}\text { Meeting the required } \\
\text { specifications of the } \\
\text { resources }\end{array}$ & $\begin{array}{l}\text { Specifications, sizes, and mold of material and other resources } \\
\text { entering the plant should match the design diagram. Reduces the } \\
\text { resource and manpower required for secondary processing or } \\
\text { reworking (to maintain quality) }\end{array}$ & Defects \\
\hline $\begin{array}{l}\text { 2. Quantity } \\
\text { Arrangement }\end{array}$ & $\begin{array}{l}\text { Maintaining the opti- } \\
\text { mal quantity of re- } \\
\text { sources as required by } \\
\text { the operation }\end{array}$ & $\begin{array}{l}\text { Input material and other resources should be delivered in batches } \\
\text { based on the planned work procedure. The amount of input ma- } \\
\text { terial and other resources should not be excessive or delivered all } \\
\text { at once so as to avoid taking up extra work space, affecting mov- } \\
\text { ing space, and incurring material arrangement expenses }\end{array}$ & $\begin{array}{l}\text { Over- } \\
\text { production }\end{array}$ \\
\hline $\begin{array}{l}\text { 3. Time } \\
\text { Arrangement }\end{array}$ & $\begin{array}{l}\text { Matching the time } \\
\text { required for the opera- } \\
\text { tion }\end{array}$ & $\begin{array}{l}\text { Material and other resources entering the site must be delivered } \\
\text { on time as specified }\end{array}$ & Delays \\
\hline $\begin{array}{l}\text { 4. Inventory Place } \\
\text { Arrangement }\end{array}$ & $\begin{array}{l}\text { Appropriate resources } \\
\text { storage place and } \\
\text { approach }\end{array}$ & $\begin{array}{l}\text { The piling of material (parts) must align with the sequence of } \\
\text { operating procedure specific to the site and be stored in a fixed } \\
\text { 3D storage space with codes to facilitate search }\end{array}$ & $\begin{array}{l}\text { Maintaining } \\
\text { excess inven- } \\
\text { tory }\end{array}$ \\
\hline $\begin{array}{l}\text { 5. Arrangement } \\
\text { of task number } \\
\text { and order }\end{array}$ & $\begin{array}{l}\text { Appropriate number } \\
\text { and order of tasks for } \\
\text { construction processes }\end{array}$ & $\begin{array}{l}\text { The number and order of tasks need to be defined in each work- } \\
\text { flow and in the overall project }\end{array}$ & $\begin{array}{l}\text { Unnecessary } \\
\text { processing }\end{array}$ \\
\hline $\begin{array}{l}\text { 6. Path } \\
\text { Arrangement }\end{array}$ & $\begin{array}{l}\text { Moving space for } \\
\text { transportation }\end{array}$ & $\begin{array}{l}\text { Specify fixed transportation paths (including paths for horizontal } \\
\text { transportation and vertical lifting) on the site of operation }\end{array}$ & $\begin{array}{l}\text { Unnecessary } \\
\text { transport }\end{array}$ \\
\hline $\begin{array}{l}\text { 7. Location } \\
\text { Arrangement }\end{array}$ & $\begin{array}{l}\text { Location of people } \\
\text { and equipment for } \\
\text { construction or instal- } \\
\text { lation }\end{array}$ & $\begin{array}{l}\text { Adhere to the locations of material, manpower, machine, and } \\
\text { equipment planned in advance for construction or installation } \\
\text { (material and other resources need be well placed to facilitate } \\
\text { retrieval and construction) }\end{array}$ & $\begin{array}{l}\text { Unnecessary } \\
\text { movement of } \\
\text { people and } \\
\text { equipment }\end{array}$ \\
\hline
\end{tabular}


to the Construction Planning Department, the Subcontracting Center, and the Site Project Management, the Specialized Contractor is distinguished from the Subcontracting Center, changing the passive role of subcontractors. The Seven-Arrangement operation plan is used by the subcontractors. The subcontractors not only provide quotes to the Subcontracting Center but also participate in the evaluation of the construction operation. In addition, both the main contractor and the subcontractors can gain their expected benefit through benefit sharing. In this way, their relationship is no longer competitive but cooperative. Doing so further streamlines the whole operational flow to achieve a full-scale integration of resources. Figure 3 presents a flowchart corresponding to the proposed LSPP. The features of the proposed LSPP are shown in shaded boxes for differentiation from the traditional operational flow. Below, we describe the four related parties involved in the LSPP flow:

\section{(1) Construction Planning Department}

After the Site Project Management proposes a subcontracting plan, the operations of the Construction Planning Department begin. First, the Construction Planning Department selects the construction method and work items and reviews and modifies the subcontracting plan based on the guidelines. Next, value and engineering analyses are introduced for an overall comparison of quality, cost, and construction period to identify the solutions that best fit the construction project. Then, the shortlisted solutions are discussed at the construction planning meeting, where a construction method is selected. Traditionally, the task of the Construction Planning Department is completed after the selection of construction method. However, with the introduction of the LSPP, the sequence of the whole construction project must be arranged based on the construction method and visualized via a $3 \mathrm{D}$ simulation model. The main purpose of this process is to enable the subcontractors to develop a thorough understanding of the operation of the site project prior to the actual work. Not only does this process help subcontractors understand the risks involved in the construction operation, the $3 \mathrm{D}$ simulation model can also satisfy the operational requirement of bringing out the benefit of understanding the whole construction process and reducing communication barriers.

\section{(2) Specialized Contractor}

In the traditional procurement model, the only role of the subcontractors is to provide risk assessment and quotes. Under the LSPP, after the Subcontracting Center selects the appropriate subcontractors, the subcontractors review and evaluate the construction operational flow and study the 3D simulation model of the main body construction procedure. Then, the subcontractors review the items required for matching by the main contractor and respond to the construction operational interface through the 3D simulation model. Finally, the subcontractors propose the manpower, equipment, and other resources necessary for the project and provide risk and quotes of each item to the Subcontracting Center. As a result, the subcontractors achieve the final construction contract based on the basis of profit sharing, quality, and schedule.

\section{(3) Site Project Management}

The Site Project Management proposes a subcontracting plan based on the Seven Arrangements in a single progress table, while adjusting the operating sequence and actual work rate of each subcontractor based on the subcontracting plan. The Site Project Management also reviews the Seven-Arrangement operation plan together with the Subcontracting Center to readjust the construction detail progress table and review the best conditions of the construction sequence, operating zone, and overlapping operation layout of each work item based on the division of construction area. Finally, the Site Project Management executes the plan based on the result of the subcontracting and adjusts the construction type and construction sequence at any time to match the common plan and construction situation.

\section{(4) Subcontracting Center}

The project subcontracting plan proposed by the Site Project Management is reviewed. Based on this review, the project is carried out according to the SevenArrangement operation plan with three important stages. First, the overall Seven-Arrangement operation plan for the project is proposed. Then, the Seven Arrangements of single procedures are reviewed based on the construction progress and construction method. Finally, the work rate, cost, and work period analysis related to the Seven Arrangements are made. On the completion of the SevenArrangement operation plan and analysis, the estimated procurement unit price is established to begin the procurement operation, the selection of suitable subcontractors, the analysis of the actual construction sequences, the operational unit (labor and material) of each awarded subcontractor, and the proposal of a divisional operating plan based on the construction site. Next, subcontractors are guided to specify the actual quantity of manpower, equipment, and material, and estimate the shortest working path and waiting time for halting work. The subcontractor needs to quickly engage in discussion with the Subcontracting Center during the presentation of the construction case, the operation path, material entering the field, and piling space location via the 3D simulation model. Each subcontractor reviews the risk of the work, so that the final negotiation may reach a procurement price that ensures maximum profit and sharing profit for the main contractor and all subcontractors. Finally, the plan is carried out based on the result of the above process.

In the LSPP, a detailed operation plan is introduced to establish a complete set of work modes that achieve economic benefit and provide contractors with an accurate $3 \mathrm{D}$ model of the manpower, equipment, material, construction method, and paths involved in the project. In addition to satisfying the needs of construction project management, the LSPP could further reduce the wait time and waste incurred on the part of the subcontractor because it obtains a lean subcontracting result that improves 
the overall performance of the site project and lowers costs. Moreover, the four types of standard operating flows in the LSPP provide a common information platform and a cooperative environment for contractors, who not only receive their expected profit in the present project but together gain potential long-term benefits.

\section{Case studies and discussions}

The research demonstrated the accuracy and usefulness of the proposed LSPP by some real projects, and the following case was described as an example. Based on the LSPP is designed, we used four case studies to explain the difference after introducing the proposed process. One case study was detailed, and it is the procurement items of New Construction of Land Office Catastrophe Prevention Center.

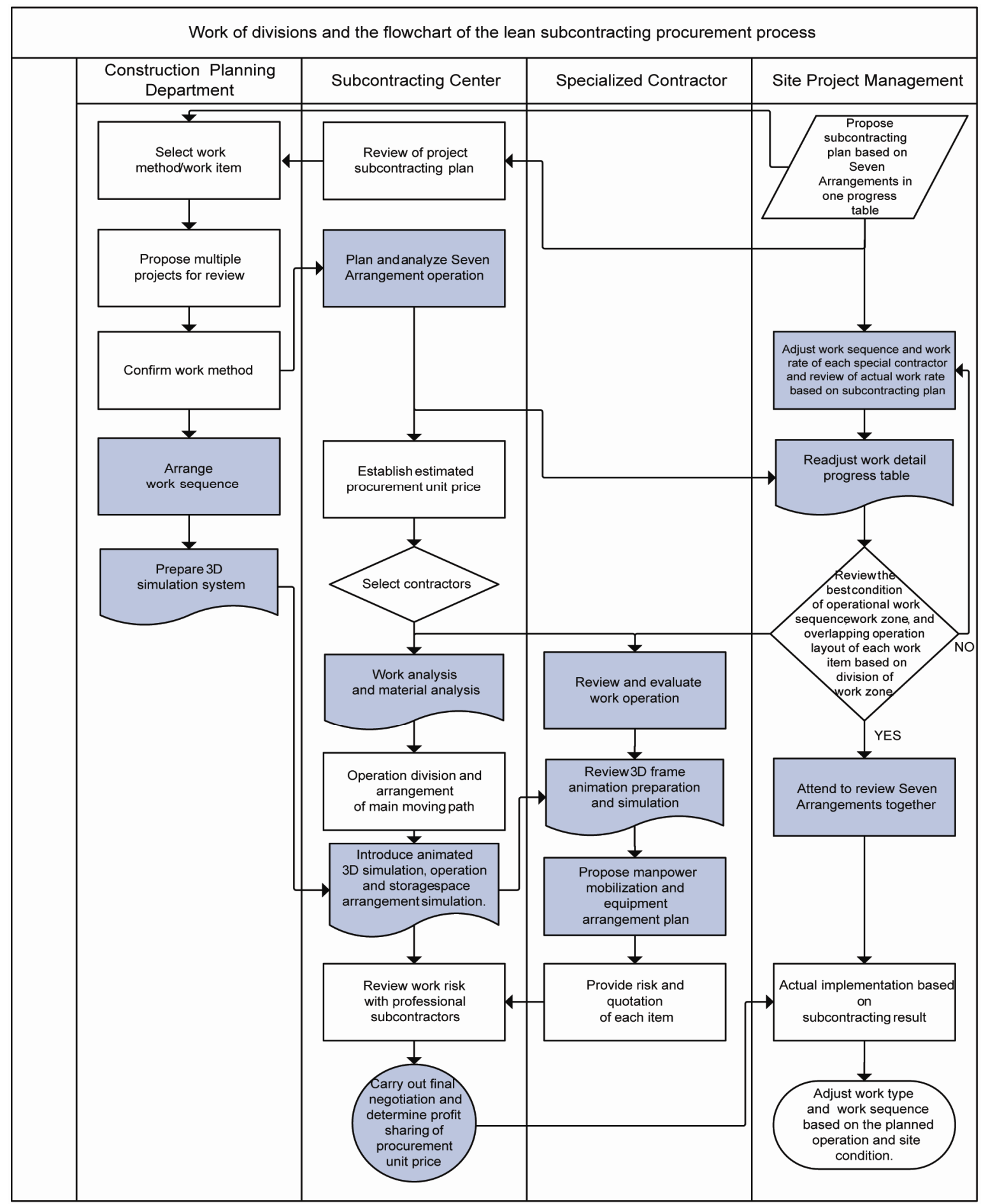

Fig. 3. Work of divisions and the flowchart of the lean subcontracting procurement process 


\subsection{The Seven-Arrangement operation plan and 3D simulation model of case study}

This case study uses steel decking as an example. Because steel decking is a critical path in the precast and launching method, all accompanying operations on the deck can only start after the laying of the steel deck. Therefore, it is necessary to explain to the specialized contractor the flow of the whole precast and launching structure before the laying of the steel deck. This structural flow is simulated using a 3D model to quickly introduce contractors to the construction case, to explain how the work is to be performed smoothly, to lower communication barriers and to reduce the waste incurred in the subsequent work. As a result, the contractors could gain an understanding of the construction sequence and moving path in each stage of the construction.

(1) Arrangements of task number and order, time, quality, quantity, and inventory

Each floor is partitioned into 24 Zones, with the horizontal coordinates represented alphabetically starting from $\mathrm{A}$ and the vertical coordinates represented numerically starting from 1 . For the first digit in each code, $\mathrm{S}$ represents south and $\mathrm{N}$ represents north with Line 4 as the demarcation. For the second digit in each code, a letter is used for each Zone to avoid confusion with the numbers used for the construction sequence as shown in Figure 4. This construction site has an area of approximately $2,000 \mathrm{~m}^{2}$. The plan is to pack the steel decking nail into 24 packs with the weight of $800-1,000 \mathrm{~kg}$ per pack. The weight of the whole floor is approximately 23 tons as the capacity of a dray. The material and equipment must be scheduled to arrive at the arranged storage area or the storage area with shortest transportation distance. Materials for all floors are shipped together simultaneously. The 24 packs of materials are arranged based on length and differentiated by their use in the north and south Zones. The launching area requires $6 \times 4 \mathrm{~m}$ of space for each Zone. To reduce secondary waste, the material is placed based on the requirement of each construction job-site instead of stored all in a single area.

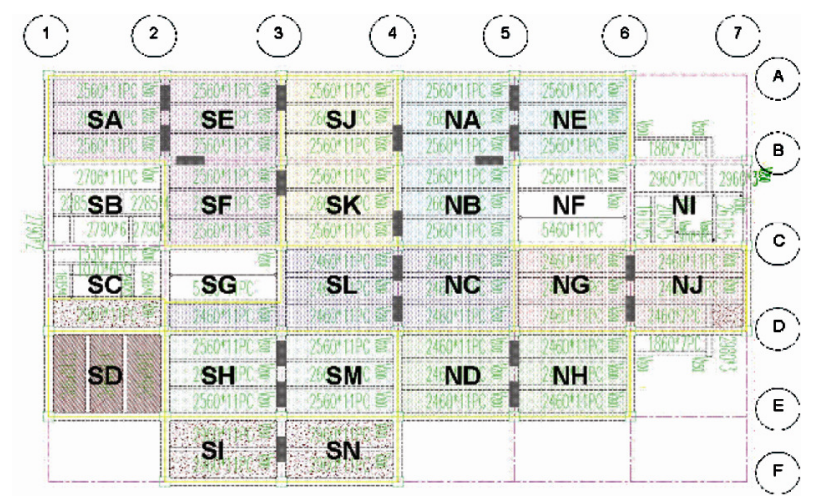

Fig. 4. Diagram of division of the area

Table 3 shows the laying sequence of steel decking based on the date. The area is divided into south Zones and north Zones. Time of input material is 5:30 AM of the fourth day; materials for south Zones are placed in one place (A; 1-2 Line) while materials for north Zones are placed in the other place (A-B; 7-8 Line). The working order of Zones corresponding to tower cranes is defined. Green represents the portion already completed during the past several working days. The location and working order of the tower cranes are also shown in the Table 3. Table 3 helps to eliminate conflicts between tower cranes and ensure that materials arrive at the construction site on time.

In this case study, the deck type and the quality of bottom deck in each area, the steel decking requirement plan, and the manpower requirement are also provided. Table 4 is an example of steel deck dimension and quality of each Zone for 1F bottom deck. Because the deck dimension and quantity in each Zone is different, it is difficult to manufacture, transport, and install without correct data. Thus, Table 4 provides the necessary data to facilitate such processes and allow the steel decks with the same dimension to be produced at the same time. The steel decks in the same Zone will be tied in a pack and transported to the appropriate place. Table 5 is an example of the steel decking requirement plan of $1 \mathrm{FL}$ and $2 \mathrm{FL}$. The specification and temporary storage of steel decks is shown in Table 5. Because the quantity of steel used for decking differs daily, Table 5 helps the subcontractor to make more effective plans with regard to resources, transport, and storage. Table 6 displays the manpower requirement for this work. As shown in Table 6, there is a gradual reduction in the manpower distribution in the 1FL construction stage and subsequent stages, whereas the level of efficiency increases due to the learning curve, the matching of the moving space, and continued work. As a result, Table 6 demonstrates the differences resulting from the application of the SevenArrangement operation plan. Specifically, the number of workers is reduced to fewer than 30 people with a working time from $8 \mathrm{AM}$ to $10 \mathrm{AM}$ and fewer than 19 people with a working time from $8 \mathrm{AM}$ to $10 \mathrm{PM}$. Thus, the SevenArrangement operation plan enables the appropriate arrangement of manpower, materials, and equipment.

\section{(2) Path and location arrangements}

The analysis confirmed the number, tonnage, work radius, and accurate location of launching tower cranes, and also planned the route of loading trucks and the launching position. As shown in Figure 5, trucks can only park in the launching area because all other areas must remain clear. These arrangements made the material flow smoother and prevented interruptions of the steel decking sequence.

\section{(3) A 3D simulation model}

In this step, the MicroStation TriForma software (Bentley 2004) was used to simulate the construction process. This software creates $3 \mathrm{D}$ print-ready models and allows users to efficiently create and edit 3D models of complex projects. MicroStation TriForma software provides a robust set of capabilities for object management, geometric modeling, information and standards management, visualization, drawing and report extraction, integration with analytical tools, interference review, etc. 
Table 3. Illustration of the $1 \mathrm{~F}$ bottom deck launching sequence

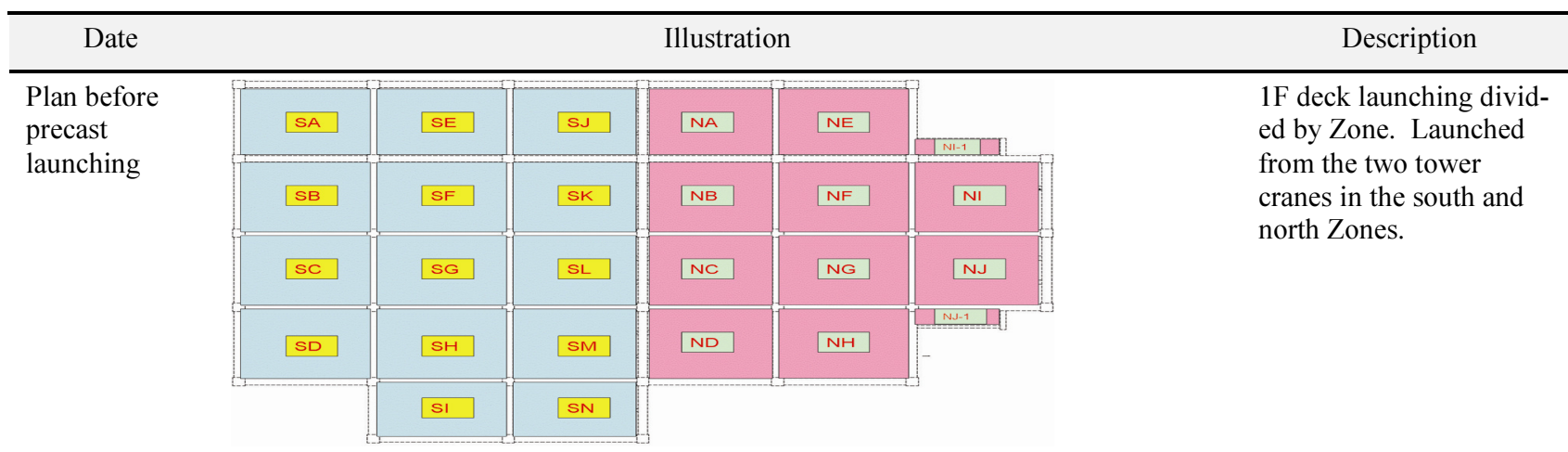

The fourth day of the precast launching

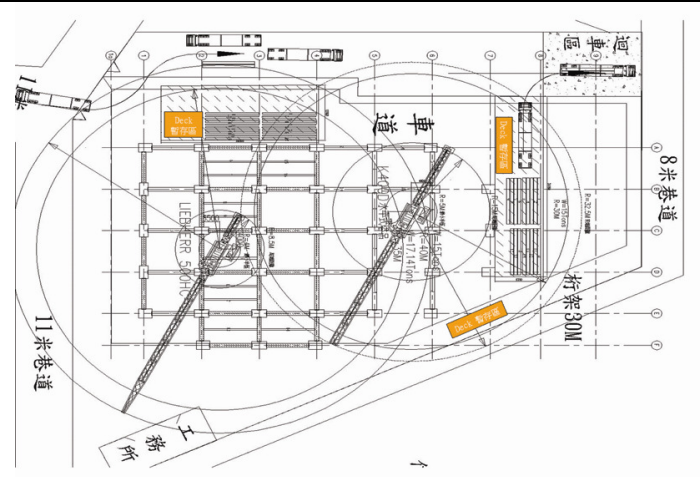

$1 \mathrm{~F}$ bottom deck input area. Time of input material is $05: 30$ of the fourth day. Serial No. 11-24 of the packed materials are placed in the A; 1-2 Line of the south Zone, and materials for the north Zones are temporarily placed in the A-B; 7-8 Line.

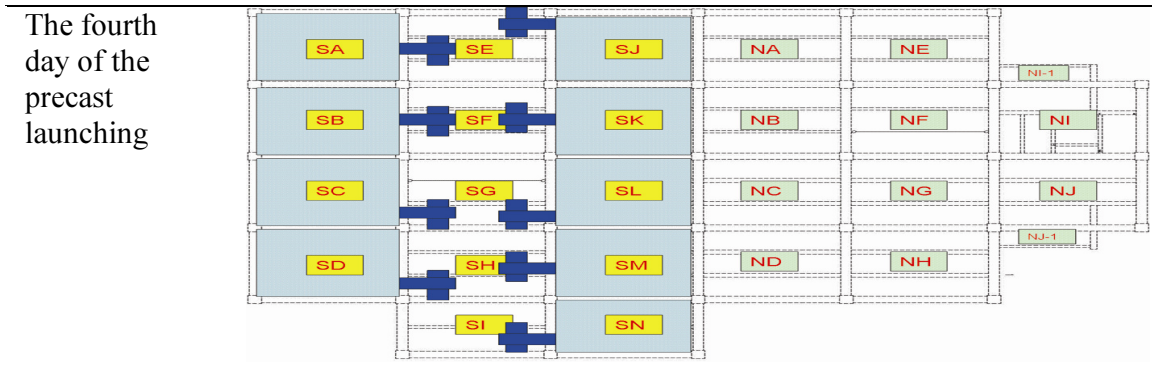

1F bottom deck installation sequence. Range of launching tower crane starts from outer edge and considers the pedestrian path by paving from the position of the staircase.

\section{The fifth day of the precast launching}

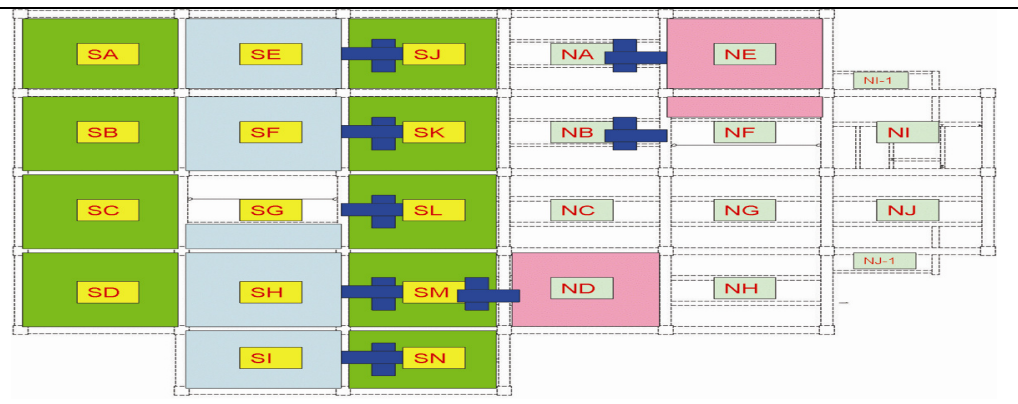

1F bottom deck installation sequence. The operation in the north Zone will start as soon as the laying of steel decking in the south is completed.

\section{The sixth day of the precast} launching

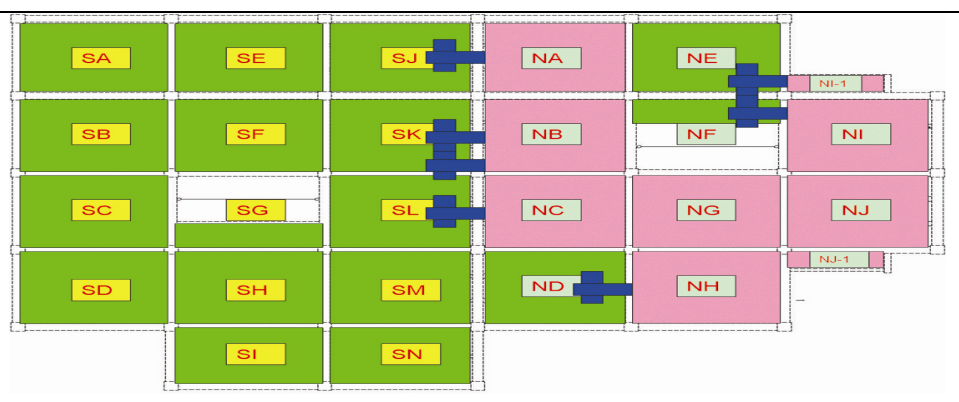

1F bottom deck installation sequence. Installation in the north Zones is completed after the sixth day of precast decking. 
Table 4 . Deck type and quantity at $1 \mathrm{~F}$ bottom deck in each area

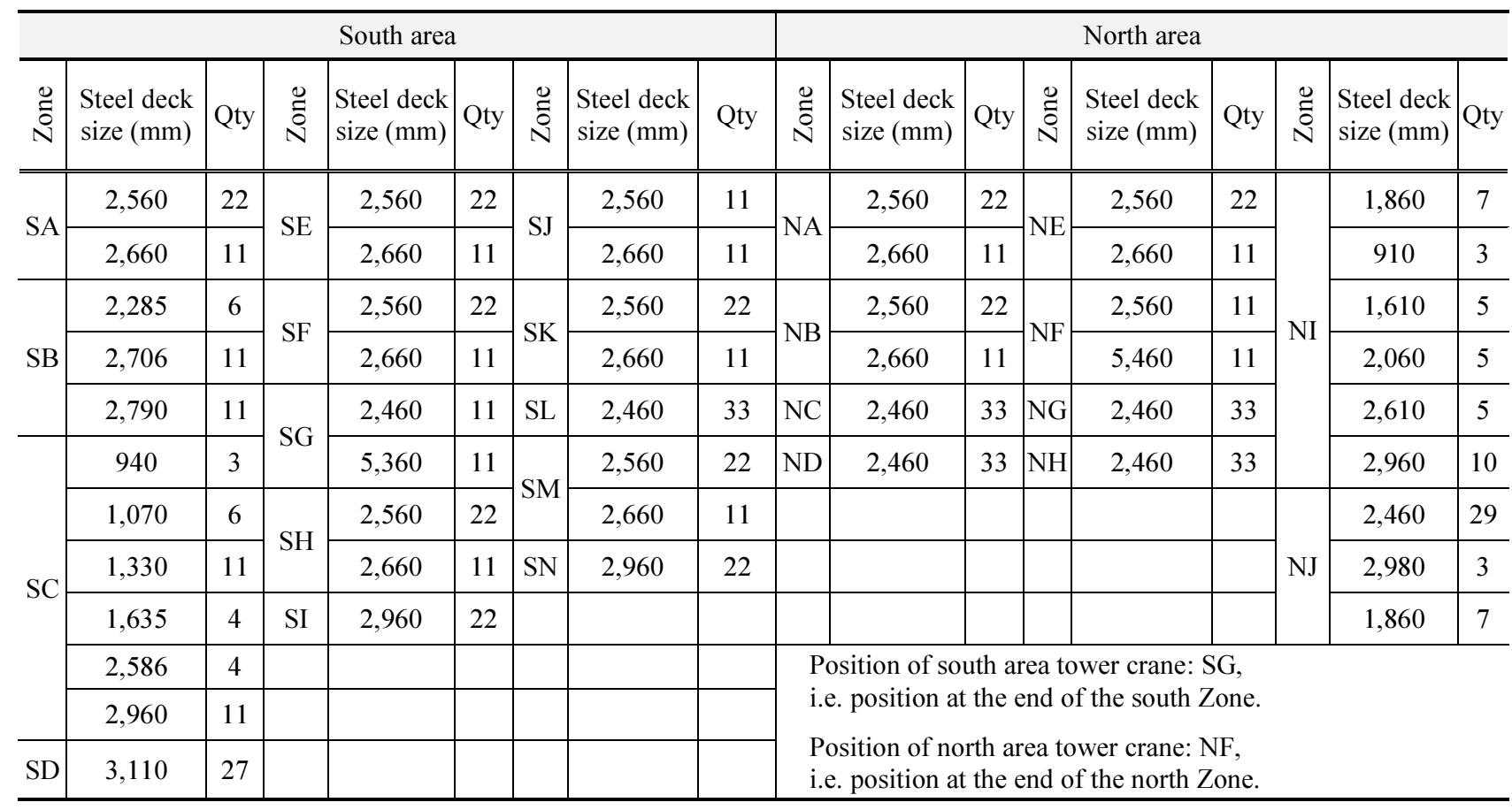

Table 5. Steel decking requirement plan

\begin{tabular}{c|c|c|c|c|c|c|c}
\hline \multirow{2}{*}{ Work item } & Input quantity & Temporary storage & Specifications & Date & Qty used & Balance & $\begin{array}{c}\text { Cumulative } \\
\text { usage }\end{array}$ \\
\hline \multirow{3}{*}{ 1FL Steel decking } & $1,730 \mathrm{~m}^{2}$ & West scaffold & $(3 \mathrm{~W})^{*} 0.92 \mathrm{t} \& 1.2 \mathrm{t}$ & $6 / 7$ & $550 \mathrm{~m}^{2}$ & $1,180 \mathrm{~m}^{2}$ & $550 \mathrm{~m}^{2}$ \\
\cline { 2 - 8 } & & West scaffold & $(3 \mathrm{~W})^{*} 0.92 \mathrm{t} \& 1.2 \mathrm{t}$ & $6 / 8$ & $550 \mathrm{~m}^{2}$ & $630 \mathrm{~m}^{2}$ & $1,100 \mathrm{~m}^{2}$ \\
\hline \multirow{3}{*}{ 2FL Steel decking } & & West scaffold & $(3 \mathrm{~W})^{*} 0.92 \mathrm{t} \& 1.2 \mathrm{t}$ & $6 / 9$ & $630 \mathrm{~m}^{2}$ & $0 \mathrm{~m}^{2}$ & $1,730 \mathrm{~m}^{2}$ \\
\cline { 2 - 8 } & & West scaffold & $(3 \mathrm{~W})^{*} 0.92 \mathrm{t} \& 1.2 \mathrm{t}$ & $6 / 19$ & $650 \mathrm{~m}^{2}$ & $1,172 \mathrm{~m}^{2}$ & $2,380 \mathrm{~m}^{2}$ \\
\cline { 2 - 8 } & & West scaffold & $(3 \mathrm{~W})^{*} 0.92 \mathrm{t} \& 1.2 \mathrm{t}$ & $6 / 20$ & $670 \mathrm{~m}^{2}$ & $502 \mathrm{~m}^{2}$ & $3,050 \mathrm{~m}^{2}$ \\
\hline
\end{tabular}

Table 6. Steel docking manpower requirement

\begin{tabular}{|c|c|c|c|c|c|c|c|c|c|}
\hline \multicolumn{10}{|c|}{ Steel docking manpower requirement } \\
\hline \multirow{5}{*}{ 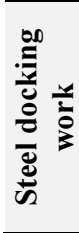 } & Date & $6 / 7$ & $6 / 8$ & $6 / 9$ & $6 / 19$ & $6 / 20$ & $6 / 21$ & $6 / 27$ & $6 / 28$ \\
\hline & Zone & $1 \mathrm{FL}$ & $1 \mathrm{FL}$ & 1FL & $2 \mathrm{FL}$ & $2 \mathrm{FL}$ & $2 \mathrm{FL}$ & $3 \mathrm{FL}$ & $3 \mathrm{FL}$ \\
\hline & Time & $\begin{array}{l}\text { AM08 : 00 } \\
\text { PM05 :00 }\end{array}$ & $\begin{array}{l}\text { AM08 : 00 } \\
\text { PM05 : } 00\end{array}$ & $\begin{array}{l}\text { AM08 : 00 } \\
\text { PM05 : 00 }\end{array}$ & $\begin{array}{l}\text { AM08 : 00 } \\
\text { PM05 :00 }\end{array}$ & $\begin{array}{l}\text { AM08 : 00 } \\
\text { PM05 : 00 }\end{array}$ & $\begin{array}{l}\text { AM08:00 } \\
\text { AM12:00 }\end{array}$ & $\begin{array}{l}\text { AM08 : 00 } \\
\text { PM10 }: 00\end{array}$ & $\begin{array}{l}\text { AM08:00 } \\
\text { AM10:00 }\end{array}$ \\
\hline & Total hour & \multirow{2}{*}{\multicolumn{3}{|c|}{24 hours for the whole area of $1 \mathrm{FL}$}} & \multirow{2}{*}{\multicolumn{3}{|c|}{20 hours for the whole area of $2 \mathrm{FL}$}} & \multirow{2}{*}{\multicolumn{2}{|c|}{$\begin{array}{c}14 \text { hours for the whole } \\
\text { area of } 3 \mathrm{FL}\end{array}$}} \\
\hline & & & & & & & & & \\
\hline \multirow{3}{*}{ 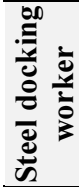 } & $\begin{array}{c}\text { No. of persons } \\
\text { planned }\end{array}$ & 10 & 8 & 8 & 15 & 10 & 5 & 16 & 15 \\
\hline & $\begin{array}{c}\text { No. of actual } \\
\text { persons }\end{array}$ & 12 & 9 & 10 & 12 & 8 & 5 & 18 & 6 \\
\hline & Difference & 2 & 1 & 2 & -3 & -2 & 0 & 2 & -9 \\
\hline \multirow{5}{*}{ 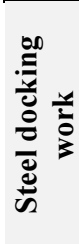 } & Date & $7 / 6$ & $7 / 7$ & $7 / 18$ & $7 / 19$ & $7 / 27$ & $7 / 28$ & $8 / 4$ & $8 / 5$ \\
\hline & Zone & 4FL & $4 \mathrm{FL}$ & $5 \mathrm{FL}$ & $5 \mathrm{FL}$ & $6 \mathrm{FL}$ & $6 \mathrm{FL}$ & $7 \mathrm{FL}$ & $7 \mathrm{FL}$ \\
\hline & Time & AM08: 00 & AM08:00 & AM08:00 & AM08:00 & AM08:00 & AM08:00 & AM08:00 & AM08:00 \\
\hline & 1ानात & PM10 : 00 & AM10:00 & PM10 : 00 & AM10 : 00 & PM10 : 00 & AM10:00 & PM10 : 00 & AM10 : 00 \\
\hline & Total hour & \multicolumn{2}{|c|}{$\begin{array}{c}14 \text { hours for the whole area } \\
\text { of } 4 \mathrm{FL}\end{array}$} & \multicolumn{2}{|c|}{$\begin{array}{l}14 \text { hours for the whole } \\
\text { area of } 5 \mathrm{FL}\end{array}$} & \multicolumn{2}{|c|}{$\begin{array}{c}14 \text { hours for the whole } \\
\text { area of } 6 \mathrm{FL}\end{array}$} & \multicolumn{2}{|c|}{$\begin{array}{c}14 \text { hours for the whole } \\
\text { area of } 7 \mathrm{FL}\end{array}$} \\
\hline \multirow{3}{*}{ 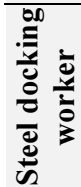 } & $\begin{array}{c}\text { No. of persons } \\
\text { planned }\end{array}$ & 16 & 15 & 20 & 8 & 18 & 6 & 20 & 8 \\
\hline & $\begin{array}{c}\text { No. of actual } \\
\text { persons }\end{array}$ & 14 & 4 & 12 & 4 & 12 & 4 & 15 & 4 \\
\hline & Difference & -2 & -11 & -8 & -4 & -6 & -2 & -5 & -4 \\
\hline
\end{tabular}




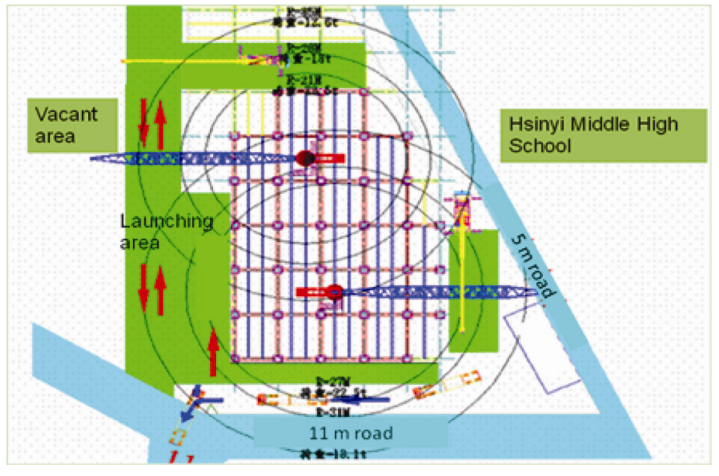

Fig. 5. Launching tower cranes layout for path arrangement

As illustrated in Figure 6, the study used a 3D model to simulate the estimated construction situation such as the construction process, the moving of trucks and cranes, and the launching area. The model facilitated the determination of potential risks, conflicts, and communication problems with other contractors and allowed subcontractors to address these issues prior to production. Moreover, the $3 \mathrm{D}$ simulation model enabled the subcontractor to improve the steel decking process, effectively reducing expenses and construction time.

\subsection{Items of the subcontracting coordination and benefits gained from the LSPP}

After using the LSPP, the steel decking procurement elements were analyzed and reviewed in consideration of the required resources, the construction sequence, the moving paths, and the interface. The negotiation items between Runhorn (the precast factory), the construction site, and the steel decking contractor (resource analysis, construction sequence, moving path analysis, and interface analysis) are consolidated as shown in Table 7. Table 7 describes the coordination and improvement items between contractors. Through conducting cost review, the savings enabled by the LSPP in the steel decking construction becomes evident. Finally, the results are provided to specialized contractors to help them understand the Seven-Arrangement operation plan for smoother implementation in the future. Below, we describe the improvements and benefits that resulted from the use of the LSPP in the steel decking construction:

\section{(1) Construction improvement}

The steel plate was available at the edge of the large beam. The small beam added the steel plate during factory production, greatly improving the speed of steel decking construction.

The short section of the steel bar fixed on the steel decking was directly provided by Dachungan with $10 \mathrm{~cm}$ cutting. The material was vacuum-packed for ease of transportation and diversion, eliminating the need for direct handling by a worker on the site.

\section{(2) Benefit of Seven Arrangements and LSPP}

Packing and serializing ensured the sufficient output of material and allowed an advanced understanding before the work commenced to enable more effective responses.

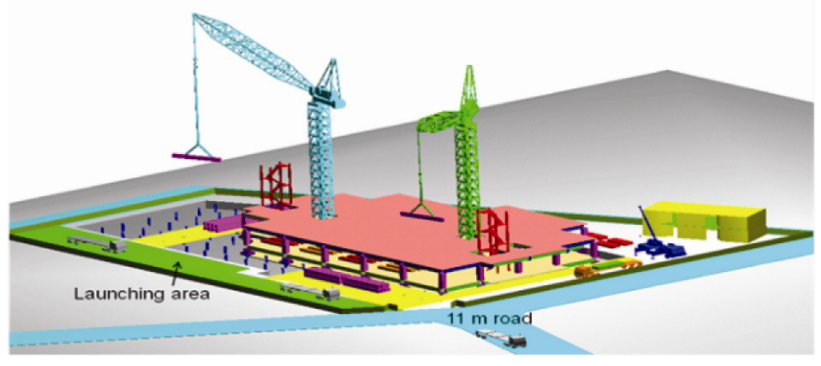

Fig. 6. A 3D simulation model

The fixed quantity of material and fixed locations for placing material by Zone reduced the distance for transportation, eliminated the problem of secondary transportation, and reduced the number of workers.

Contractors shared tower cranes and manpower, and the construction project proceeded with no conflict nor waste.

\subsection{Case studies results and analysis}

In the steel decking operation, the implementation of the Seven Arrangements in the LSPP facilitated the generation of the steel decking requirement plan, the manpower requirement plan, the tower cranes layout, the steellaminated plate coordinate location, the type and quantity of steel decking at each Zone, the launching plan, and the material piling principle. The quantity and size of the materials, the paths for moving resources, time, construction location, and storage place were planned and standardized completely prior to the beginning of construction. The results were then simulated via a $3 \mathrm{D}$ simulation model and presented to contractors to ensure an understanding of the Seven-Arrangement operation plan and reduce the confusion that might arise from interfacing difficulties. Additionally, through the subcontracting coordination items, the coordination of the final negotiation and the corresponding improvement items were presented. Finally, the cost of the coordination items were analyzed and compared with the price adjustment. Thus, savings were made possible by the LSPP and the ratio of benefit sharing with the professional subcontractors could be determined.

In the case study, a shorter construction period was observed. The construction period for steel decking precast (10 days per layer) was reduced from the original duration of 3 working days to 1.5 working days after using the LSPP. Again, because the steel layer plate was a critical path, the construction period was reduced from 10 days to 8.5 days. The total laying area of steel decking was $13,688 \mathrm{~m}^{2}$, with the original estimated wage of installation being $\$ 70 / \mathrm{m}^{2}$ (i.e. total price $\$ 958,160$ ). Resource analysis showed that the laying of precast launching and steel decking shared tower cranes launching with the saving of original steel decking laying in roller launching expense of $\$ 68,440$, resulting in a reduction of the total price to $\$ 889,720$ and the unit price for installation to $\$ 65 / \mathrm{m}^{2}$. These reductions resulted from the cooperation 
Table 7. Subcontracting coordination items

\begin{tabular}{|c|c|c|c|c|c|c|c|c|c|}
\hline \multirow{2}{*}{ Item } & \multicolumn{4}{|c|}{ Coordination items } & \multicolumn{5}{|c|}{ Improvement items } \\
\hline & \multicolumn{3}{|c|}{ Content } & Attachment & \multicolumn{2}{|c|}{ Risk involved } & \multicolumn{3}{|c|}{ Improvement countermeasure } \\
\hline 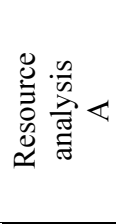 & \multicolumn{3}{|c|}{$\begin{array}{l}\text { 1. Share tower launch with precast. } \\
\text { 2. Manpower } 6 \text { persons per day. }\end{array}$} & $\begin{array}{l}\text { 1. Material } \\
\text { packing plan } \\
\text { diagram. } \\
\text { 2. Shipment } \\
\text { detail form. }\end{array}$ & \multicolumn{2}{|c|}{$\begin{array}{l}\text { 1. Delay of previous } \\
\text { work item. } \\
\text { 2. Insufficient workers } \\
\text { and frequent changes } \\
\text { in personnel. }\end{array}$} & \multicolumn{3}{|c|}{$\begin{array}{l}\text { 1. Put progress under control. Add } \\
\text { rotating support if necessary. } \\
\text { 2. Fix work shift. Stabilize manpow- } \\
\text { er resource. } \\
\text { 3. Sharing of tower cranes launch. } \\
\text { Save rotation expense. }\end{array}$} \\
\hline 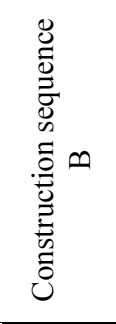 & \multicolumn{3}{|c|}{$\begin{array}{l}\text { Meet with Runhorn, construction site, and } \\
\text { contractors for discussion and confirm } \\
\text { construction sequence: } \\
\text { 1. Accommodate division of launching } \\
\text { tower into south and north Zone for } \\
\text { work. } \\
\text { 2. After the fourth day of precast launch- } \\
\text { ing, steel decking enters the site for } \\
\text { work and is completed on the sixth day. }\end{array}$} & $\begin{array}{l}\text { 1. Launching } \\
\text { construction } \\
\text { sequence by } \\
\text { Zone. }\end{array}$ & \multicolumn{2}{|c|}{$\begin{array}{l}\text { 1. Delay of precast } \\
\text { launching. Steel } \\
\text { decking waits after } \\
\text { entering the site. }\end{array}$} & \multicolumn{3}{|c|}{$\begin{array}{l}\text { 1. All construction types come to } \\
\text { agreement before work. Make sure } \\
\text { daily progress is completed. }\end{array}$} \\
\hline 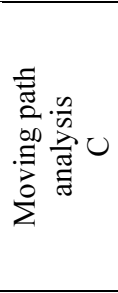 & \multicolumn{3}{|c|}{$\begin{array}{l}\text { 1. Each floor output material without dif- } \\
\text { ferentiation. Dray enters the site from } \\
\text { west side. } \\
\text { 2. Input time at } 05: 30 \text { on the fourth day of } \\
\text { precise launching. Place material pack } \\
\text { No. 11-24 of south Zone at A; } 1-2 \text { Line. } \\
\text { North Zone material placed at A-B; 7-8 } \\
\text { Line. }\end{array}$} & $\begin{array}{l}\text { 1. 3D frame CD } \\
\text { ROM. } \\
\text { 2. Surface mov- } \\
\text { ing path dia- } \\
\text { gram. }\end{array}$ & \multicolumn{2}{|c|}{$\begin{array}{l}\text { 1. Delay in time of } \\
\text { material input. Clash } \\
\text { in timing of machine, } \\
\text { people, and material. } \\
\text { 2. Improper plan of } \\
\text { material piling posi- } \\
\text { tion. }\end{array}$} & \multicolumn{3}{|c|}{$\begin{array}{l}\text { 1. Plan for floating time. Reserve } \\
\text { room for changes. } \\
\text { 2. Use 3D to simulate feasibility. }\end{array}$} \\
\hline 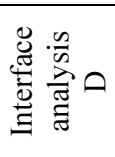 & \multicolumn{3}{|c|}{$\begin{array}{l}\text { 1. Timing of steel decking input must } \\
\text { avoid timing of precast material. } \\
\text { 2. Steel decking material must avoid the } \\
\text { main progress of precast launching time. }\end{array}$} & $\begin{array}{l}\text { 1. 1F and work- } \\
\text { ing floor ma- } \\
\text { terial piling } \\
\text { diagram. }\end{array}$ & & & & & \\
\hline \multirow{4}{*}{ 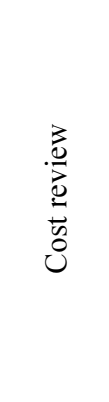 } & \multirow{2}{*}{$\begin{array}{l}\text { Corre- } \\
\text { spond- } \\
\text { ing item }\end{array}$} & \multicolumn{2}{|c|}{$\begin{array}{l}\text { Unit price analysis } \\
\text { (Taiwan dollar) }\end{array}$} & \multirow{2}{*}{$\begin{array}{l}\text { Total savings } \\
\text { (Taiwan dollar) }\end{array}$} & \multirow{2}{*}{$\begin{array}{l}\text { Savings } \\
\text { rate }\end{array}$} & \multirow{2}{*}{\multicolumn{2}{|c|}{$\begin{array}{l}\text { Unit price adjustment } \\
\text { (Taiwan dollar) }\end{array}$}} & \multicolumn{2}{|c|}{$\begin{array}{l}\text { Profit sharing } \\
\text { (Taiwan dollar) }\end{array}$} \\
\hline & & Original quotation & Saving & & & & & Contractor & Pin Huei \\
\hline & A & $\begin{array}{l}\text { Installation wage } \\
\text { quotation } \$ 70 / \mathrm{m}^{2} \\
\text { (Total price } \\
\$ 958,160) \\
\end{array}$ & $\begin{array}{l}\text { Cost differ- } \\
\text { ence } \$ 68,440\end{array}$ & $\$ 68,440$ & $7.14 \%$ & $\begin{array}{r}\text { Installatic } \\
\$ 65 /\end{array}$ & $\begin{array}{l}\text { on wage } \\
/ \mathrm{m}^{2}\end{array}$ & Nil & $\$ 68,440$ \\
\hline & $\mathrm{B}$ & & $\begin{array}{c}\text { Waste due to } \\
\text { waiting } \\
\$ 88,972\end{array}$ & $\$ 88,972$ & $10.00 \%$ & $\begin{array}{r}\text { Installatic } \\
\$ 58.5\end{array}$ & $\begin{array}{l}\text { on wage } \\
5 / \mathrm{m}^{2}\end{array}$ & $\begin{array}{l}\text { Da Biao } \\
\text { share } \\
\$ 44,486\end{array}$ & $\begin{array}{l}\text { Da Biao } \\
\text { share } \\
\$ 44,486\end{array}$ \\
\hline
\end{tabular}

Table 8. Results of the implementation of LSPP in several case studies

\begin{tabular}{|c|c|c|c|c|c|c|c|}
\hline \multirow[b]{2}{*}{ 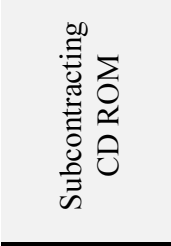 } & \multirow[b]{2}{*}{ 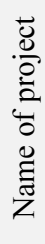 } & \multirow[b]{2}{*}{ Content } & \multicolumn{5}{|c|}{ Cost reduction analysis } \\
\hline & & & $\begin{array}{c}\text { Total price of } \\
\text { contract } \\
\text { (Taiwan dollar) }\end{array}$ & $\begin{array}{c}\text { Subcontracting } \\
\text { budget } \\
\text { (Taiwan dollar) }\end{array}$ & $\begin{array}{c}\text { Potential cost reduc- } \\
\text { tions or the amount of } \\
\text { lowered price to be } \\
\text { shared with contractors } \\
\text { (Taiwan dollar) }\end{array}$ & $\begin{array}{l}\% \text { Cost } \\
\text { reduced }\end{array}$ & $\begin{array}{l}\text { Subcontracting } \\
\text { performance: } \\
\text { \% reduction } \\
\text { compared to } \\
\text { budget }\end{array}$ \\
\hline Mode plate & A & \multirow{4}{*}{$\begin{array}{l}\text { 1. 3D frame/ moving path } \\
\text { 2. Work guideline } \\
\text { 3. Uniform work diagram } \\
\text { 4. Subcontracting checklist }\end{array}$} & $\$ 22,009,064$ & $\$ 25,375,619$ & $\$ 2,273,825$ & $10.3 \%$ & $22.2 \%$ \\
\hline $\begin{array}{l}\text { Cement } \\
\text { compression } \\
\text { and transfer }\end{array}$ & A & & $\$ 1,362,944$ & $\$ 1,626,240$ & $\$ 185,856$ & $13.6 \%$ & $27.6 \%$ \\
\hline Pile & B & & $\$ 24,637,681$ & $\$ 28,546,200$ & $\$ 850,000$ & $3.5 \%$ & $16.7 \%$ \\
\hline $\begin{array}{l}\text { Steel deck- } \\
\text { ing }\end{array}$ & $\mathrm{C}$ & & $\$ 958,160$ & $\$ 1,077,930$ & $\$ 157,412$ & $16.4 \%$ & $25.7 \%$ \\
\hline \multicolumn{3}{|r|}{ Total } & $\$ 48,967,849$ & $\$ 56,625,989$ & $\$ 3,467,093$ & $7.1 \%$ & $19.7 \%$ \\
\hline
\end{tabular}


made possible by the LSPP. Furthermore, via cost review and analyses of moving paths and the interface, wasted wages incurred by waiting for material and tower cranes were eliminated with the saving of $10 \%$ of total cost (or $\$ 88,972$ ). The installation wage was reduced to $\$ 58.5 / \mathrm{m}^{2}$, and the total cost was reduced by $16.4 \%$. These savings are also the result of using the Seven-Arrangement operation plan. In this case study, the LSPP allowed the adjustment of contracting agreement items for cost reduction and shortened construction time.

The productivity of the steel-laminated plate operation was compared before and after applying the LSPP. Specifically, the LSPP shortened the construction period the original 3 days to 1.5 days, doubling the productivity. The results of this study suggest that in the context of laying steel-laminated plates, the LSPP significantly improved efficiency and reduced waste.

Table 8 presents the results of all the case studies conducted, including the one discussed earlier. There are three key results. First, the LSPP met its goals such as reducing waste, developing cooperative relationships, and sharing profit among contractors. Second, the extent of waste reduction and cooperation depended on project characteristics. Third, the projects that used more equipment and material reaped greater benefits from the implementation of LSPP.

Based on feedback from four participating contractors, such as Jia-Tzu Enterprise Co., Ltd. (Mode plate case), Tzan-Ming Engineering Co., Ltd. (Cement compression and transfer case), Wei-Tai Industrial Co., Ltd. (Pile case), and Jia-De Building Materials Co., Ltd. (Steel decking case) interviewed in the case studies (shown in Table 8), one of them encountered difficulty when attempting to apply the proposed approach. For example, more extensive background knowledge was needed to endorse this novel approach and more time was needed for the preparation work. It was also challenging to replace the traditional competitive posture with a cooperative one.

\section{Conclusions}

Based on our analysis of case studies of construction projects, we recommend application of the LSPP for construction contractors. This process consists of a novel Seven-Arrangement operation plan and four types of standard operating flows. The process is very useful for both the main contractor and subcontractor for the following reasons. First, the novel Seven-Arrangement operation plan, based on the theory of lean construction, may help subcontractors eliminate various types of waste in construction projects. Second, by establishing a common information platform for contractors, the four standard operating flows may help contractors understand the work emphasis of single operation and the whole operation in sequence. As a result, cooperative relationships can develop among contractors involved in the same project, allowing for the early identification of potential risk and conflicts related to the construction. Third, the LSPP may improve the level of trust and profit sharing in the execution of construction projects. Finally, through applying the LSPP, contractors gain opportunities to apply advanced technological tools, improve innovation in construction projects, and receive long-term benefits.

Moreover, the observed results from applying this LSPP to the real projects are largely positive and consistent. Nonetheless, the research findings were limited by the numbers and types of the projects sampled for our case studies. Thus, the analysis of more projects (in terms of both number and type) is necessary to achieve more robust results. Additionally, the contractors need to have some level of background knowledge to accept this novel approach, which could have been more effective had all contractors been willing to cooperate. Also important are the effect level of each arrangement and the cooperation level between contractors in the proposed process, which represent another valuable direction for future research.

\section{Acknowledgments}

The authors would like to acknowledge the National Science Council, Taiwan, for financially supporting this work under contract number NSC-99-2218-E-002-034 and NSC-98-2622-E-002-027-CC3. The authors would also like to thank the managers and engineers of the Reuntex Group, Inc. for their assistance in this research project.

\section{References}

Abdelgawad, M.; Fayek, A. R. 2010. Risk management in the construction industry using combined Fuzzy FMEA and Fuzzy AHP, Journal of Construction Engineering and Management 136(9): 1028-1036. http://dx.doi.org/10.1061/(ASCE)CO.1943-7862.0000210

Abdullah, F. 2003. Lean manufacturing tools and techniques in the process industry with focus on steel: $\mathrm{PhD}$ Dissertation. University of Pittsburgh.

Albino, V.; Garavelli, A. C. 1998. A neural network application to subcontractor rating in construction firms, International Journal of Project Management 16(1): 9-14. http://dx.doi.org/10.1016/S0263-7863(97)00007-0

American Association of Cost Engineers (AACE). 1992. Skills and knowledge of cost engineers. $3^{\text {rd }} \mathrm{ed}$.

Arditi, D.; Chotibhongs, R. 2005. Issues in subcontracting practice, Journal of Construction Engineering and Management 131(8): 866-876. http://dx.doi.org/10.1061/(ASCE)07339364(2005)131:8(866)

Bently. 2004. Microstation TriForma [online], [cited 14 January 2006]. Available from Internet: http://www.bentley.com/enUS/Products/MicroStation/Top-Reasons.htm

Burati Jr, J. L.; Farrington, J. J.; Ledbetter, W. B. 1992. Causes of quality deviations in design and construction, Journal of Construction Engineering and Management 118(1): 34-49. http://dx.doi.org/10.1061/(ASCE)07339364(1992)118:1(34)

Cheung, S.-O.; Lam, T.-I.; Leung, M.-Y.; Wan, Y.-W. 2001. An analytical hierarchy process based procurement selection method, Construction Management and Economics 19(4): 427-437. http://dx.doi.org/10.1080/014461901300132401

Cnudde, M. 1991. Lack of quality in construction-economic losses, in Proceedings of European Symposium on 
Management, Quality and Economics in Housing and Other Building Sectors, 1991, Lisbon, 508-515.

Eom, C. S. J.; Yun, S. H.; Paek, J. H. 2008. Subcontractor evaluation and management framework for strategic partnering, Journal of Construction Engineering and Management 134(11): 842-851.

http://dx.doi.org/10.1061/(ASCE)07339364(2008)134:11(842)

Eriksson, P. E.; Laan, A. 2007. Procurement effects on trust and control in client-contractor relationships, Construction and Architectural Management 14(4): 387-399. http://dx.doi.org/10.1108/09699980710760694

Eriksson, P. E.; Westerberg, M. 2011. Effects of cooperative procurement procedures on construction project performance: a conceptual framework, International Journal of Project Management 29(2): 197-208. http://dx.doi.org/10.1016/j.ijproman.2010.01.003

Forbes, L. H.; Ahmed, S. M. 2004. Adapting lean construction methods for developing nations, in Proceedings of $2^{\text {nd }}$ LACCEI International Latin American and Caribbean Conference for Engineering and Technology (LACCEI'2004) "Challenges and Opportunities for Engineering Education, Research and Development", 2004, Miami, Florida, USA.

Greenwood, D. 2001. Subcontract procurement: are relationships changing?, Construction Management and Economics 19(1): 5-7. http://dx.doi.org/10.1080/01446190010003380

Hartmann, A.; Caerteling, J. 2010. Subcontractor procurement in construction: the interplay of price and trust, Supply Chain Management: An International Journal 15(5): 354362. http://dx.doi.org/10.1108/13598541011068288

Hartmann, A.; Ling, F. Y. Y.; Tan, J. S. H. 2009. Relative importance of subcontractor selection criteria evidence from Singapore, Journal of Construction Engineering and Management 135(9): 826-832.

http://dx.doi.org/10.1061/(ASCE)07339364(2009)135:9(826)

Hatush, Z.; Skitmore, M. R. 1998. Contractor selection using multicriteria utility theory: an additive model, Building and Environment 33(2-3): 105-115.

http://dx.doi.org/10.1016/S0360-1323(97)00016-4
Hinze, J.; Tracey, A. 1994. The contractor-subcontractor relationship: the subcontractor's view, Journal of Construction Engineering and Management 120(2): 274287. http://dx.doi.org/10.1061/(ASCE)07339364(1994)120:2(274)

Kumaraswamy, M. M.; Matthews, J. D. 2000. Improved subcontractor selection employing partnering principles, Journal of Management in Engineering 16(3): 47-57. http://dx.doi.org/10.1061/(ASCE)0742597X(2000)16:3(47)

Ohno, T. 1987. Toyota production system. Portland, OR, USA: Productivity Press.

Pesämaa, O.; Eriksson, P. E.; Hair, J. F. 2009. Validating a model of cooperative procurement in the construction industry, International Journal of Project Management 27(6): 552-559.

http://dx.doi.org/10.1016/j.ijproman.2008.10.007

Pinch, L. 2005. Lean construction: eliminating the waste, Construction EXECUTIVE: 34-37.

Radziszewska-Zielina, E. 2010. Methods for selecting the best partner construction enterprise in terms of partnering relations, Journal of Civil Engineering and Management 16(4): 510-520. http://dx.doi.org/10.3846/jcem.2010.57

Shash, A. A. 1998. Bidding practices of subcontractors in Colorado, Journal of Construction Engineering and Management 124(3): 219-225.

http://dx.doi.org/10.1061/(ASCE)07339364(1998)124:3(219)

Shimizu, J. Y.; Cardoso, F. F. 2002. Subcontracting and cooperation network in building construction: a literature review, in Proceedings of IGLC-10, 2002, Gramado, Brazil.

Yu, H.; Tweed, T.; Al-Hussein, M.; Nasseri, R. 2009. Development of lean model for house construction using value stream mapping, Journal of Construction Engineering and Management 135(8): 782-790. http://dx.doi.org/10.1061/(ASCE)07339364(2009)135:8(782)

Zavadskas, E. K.; Turskis, Z.; Tamošaitienè, J. 2009. Risk assessment of construction projects, Journal of Civil Engineering and Management 16(1): 33-46. http://dx.doi.org/10.3846/jcem.2010.03

Samuel Yen-Liang YIN is the CEO and Chief R\&D Officer of the Ruentex Group and a professor at the Department of Civil Engineering at National Taiwan University. In addition, he has a PhD in Business Management and is a Member of the Russian Academy of Engineering. He received the ASCE Henry L. Michel Award (2010) and the Engineering Glory Award by Russian Academy of Engineering (2008). His research interests include advanced techniques for pre-cast construction method, management information system, automation in construction, construction management, and project procurement management.

H. Ping TSERNG is a full Professor at the Department of Civil Engineering at National Taiwan University. He has a PhD in Construction Engineering and Management. In addition, he is a Corresponding Member of the Russian Academy of Engineering and has served as an Official Reviewer or Editorial Board Member for several international journals. His research interests include project procurement management, construction estimating and scheduling, project performance evaluation, advanced techniques for knowledge management, management information system, and automation in construction.

Shih Ning TOONG is a General Manager in M\&E of the Ruentex Group. He obtained his MSc from Bradley University, USA. His research interests include construction management, project performance evaluation, and project procurement management.

Thanh Long NGO is a PhD candidate at the Department of Civil Engineering at National Taiwan University and a Lecturer in the Department of Construction Mechanical Engineering at the National University of Civil Engineering, Hanoi, Vietnam. His research interests include project procurement management, lean construction, construction equipment, mechanical and electrical systems, and construction management. 